\title{
Nitrogen Uptake of Cocoa Seedlings as a Response to Cocoa Pod Husk Derived Liquid Organic Fertilizer Application in Combination with Urea
}

\author{
Erwin Prastowo $^{(*)}$, Irawan Dwiyanto ${ }^{2)}$, Moch Arifin ${ }^{2)}$, and Setyo Budi Santoso ${ }^{2)}$ \\ ${ }^{1)}$ Indonesian Coffee and Cocoa Research Institute, J1. PB. Sudirman No. 90, Jember, Indonesia \\ ${ }^{2}$ Faculty of Agriculture, University of Pembangunan Nasional "Veteran" East Java, \\ J1. Rungkut Madya, Surabaya, East Java, Indonesia \\ ${ }^{*}$ Corresponding author: eprastowo@iccri.net \\ Received: 10 September 2020 / Accepted: 27 November 2020
}

\begin{abstract}
As nitrogen $(\mathrm{N})$ has played an important role in cocoa production, both providing the $\mathrm{N}$-sources alternative materials, and increasing the efficiency of fertilization are urgently required to support both crop and land productivity. This research aimed to investigate the $\mathrm{N}$ uptake of cocoa seedlings as results of combination of liquid organic fertilizer (LOF) and urea applications. To support the understanding in terms of $\mathrm{N}$ dynamics, SPAD (Soil Plant Analysis Development) chlorophyll content, $\mathrm{N}$ use efficiency (NUE) and recovery of applied nitrogen (REN) were determined with additional information related to the optimal dosage of urea applied to cocoa seedlings. Greenhouse experiment, using ICCRI 08 cocoa seedling, was carried out in Kaliwining Experimental Station, Indonesian Coffee and Cocoa Research Institute, Jember, East Java. The LOF used for this experiment was made from about one month fermentation of cocoa pod waste in a $200 \mathrm{~L}$ plastic tank with additional biodecomposer to improve the biodegradation of organic materials. The experiment was designed by a completely randomized design (CRD), and taking into account two factors, i.e. the level of $\mathrm{LOH}$ concentrations and urea applications, as treatments of which their effect was determined through regular growth observations and laboratory determinations. The variation of LOF concentration levels were $0 \%, 0.25 \%, 0.50 \%$, and $1 \%$. Additionally, the rates of urea applications include control, $10 \%, 25 \%$, and $50 \%$ of fertilizer recommendation dosages. SPAD readings indicate the significant effect of urea and its combination with LOF to the increase in the chlorophyll content by $10-20 \%$ in compare to control. The total $\mathrm{N}$ uptake of cocoa tended to decrease with the increase in concentration of LOF. With an average increase of about $28 \%$ compared to control, statistical analysis suggested the insignificant different effect of treatments. The effect LOF to the increase of NUE, ranging from 0.50 to 0.80 , in combination with specific level of urea. With $50 \%$ of urea recommendation dosage, the increase in NUE was above $40 \%$ up to $55 \%$ compared to non-LOF applied treatments. REN data interpretation indicates the higher values for treatments with lower level of urea applications. With the increase in urea rates, the REN value was decreasing implying the contribution from the input of N. In this level, the REN was down to below 50\% showing the lower amount of $\mathrm{N}$ required in compared to $\mathrm{N}$ inputs. Relating the dosage of urea to $\mathrm{N}$ uptake showed an asymptotic type of curves which indicated the optimal rate of urea ranging from 0.5 to $1 \mathrm{~g}$ urea per pot. The higher amount of LOF applied showed to decrease the optimal dosage of urea required in compare to non-LOF application. Thought its use as source of nutrients is limited, current research may indicate the potential utilization of LOF through foliar spray to increase the efficiency of urea application.
\end{abstract}

Keywords: nitrogen use efficiency, nitrogen uptake, liquid organic fertilizer, cocoa pod husk 


\section{INTRODUCTION}

For getting a high yield cocoa requires an optimal nitrogen (N) (Kaba et al., 2018). It is widely recognized that $\mathrm{N}$ is important to support the vegetative phase determining the amount of cocoa pods produced during the generative stage. Additionally, $\mathrm{N}$ is also required to develop cocoa canopy and frame prior to pod production. Therefore, increasing the uptake of $\mathrm{N}$ is potentially improved the growth and overcome one of the most limiting factors for cocoa (Ribeiro et al., 2008).

Most of cocoa plantation in Indonesia now is subject to low soil fertility status with $\mathrm{N}$ content below $0.30 \%$ (Prastowo \& Baon, 2020), therefore there is a high $\mathrm{N}$ demand to support the sustainability cocoa production by increasing the $\mathrm{N}$ fertility level, and explore the potential $\mathrm{N}$ sources with lower operational cost without any environmental effect. The use of mineral derived $\mathrm{N}$ fertilizer is still the main priority for most of cocoa farmers since it is more practicable than the application organic matter derived $\mathrm{N}$ which is bulkier and more laborious. Yet application of $\mathrm{N}$ mineral fertilizer is limited to the low accessibility and unaffordable price to smallholder farmers which accounting for around $90 \%$ of total cocoa area in Indonesia.

The use of cocoa pod husk (CPH) derived compost, as an organic waste product of cocoa production, to improve soil fertility level has been reported (Oyewole et al., 2012; Kayode et al., 2018). Given that it accounts for around $70 \%$ out of total weight of pods, in the cocoa farms without any further composting facilities it may provide a great problem related to waste management (Vásquez et al., 2019; Campos-Vega et al., 2018). Additionally, the use of $\mathrm{CPH}$ as $\mathrm{N}$ source for plant is always limited by current nutrient level, commonly below $1.50 \%$ (Sugiyanto et al., 2008; Ayeni, 2010). Therefore it does not meet the Indonesian Ministry of Agriculture minimum technical criteria for organic fertilizer as it requires $\mathrm{N}$ content of $2 \%$ to be designated as solid or dried organic fertilizer. Nevertheless, it can still be categorized as liquid organic fertilizer based in the same regulation as the minimium criteria is a bit lower, i.e. $0.5 \%$. Therefore, its utilization is mostly aimed at increasing the soil fertility level through soil physical characteristics improvement such as water holding capacity, soil structure, soil texture and aeration.

However, many efforts have been made to improve the quality of fermented $\mathrm{CPH}$ such as through the addition of essential minerals and decomposers to enhance the biological processings (Nurhaita et al., 2018; Campos-Vega, 2018). Yet in the farm level, different technologies providing more simple and practical ways to improve the quality of fermented CPH may still be required. The mixture of cow urine as supplementary material for $\mathrm{CPH}$ fermentation may still be limited to our best knowledge. With $\mathrm{N}$ content of up to $1 \%$, it is potential to be utilized as liquid organic fertilizer to support crop production (Safitri et al., 2019).

Therefore, the combination of $\mathrm{CPH}$ and cow urine is not only expected to improve the quality of fermentation but also the practical way of its production. Additionally, the foliar application of fermented CPH may potentially provide a different source of $\mathrm{N}$ for cocoa while overcoming the environmental problem related to the handling of cocoa waste in the farms. Liquid product obtained from $\mathrm{CPH}$ fermentation can be provided faster and with reduced amount of dosage required for spraying, i.e. $0.5-1 \%$, in compare to the solid or dry organic material for ground application, i.e. $10-20 \mathrm{~kg}$ per tree.

Present research aims to determine the $\mathrm{N}$ uptake of cocoa seedlings as results of combination of fermented $\mathrm{CPH}(\mathrm{F}-\mathrm{CPH})$ and 
urea applications. Its association to chlorophyll content is determined through SPAD readings.

\section{MATERIALS AND METHODS}

Five months greenhouse experiment, of up to April 2020, was carried out in Kaliwining Experimental Station, Indonesian Coffee and Cocoa Research Institute, Jember, East Java. Using ICCRI 08 variety, cocoa seedlings were maintained of up to 30 days after planting to maintain a well-established crop condition before treatments. During the maintenance, all cocoa seedlings received the same amount of regular irrigation water of up to the field capacity condition.

The soil was passed through $\phi<2 \mathrm{~mm}$ sieve to improve the size homogeneity of growth media, and remove the potential mixing of non-soil fractions. The silty clay of Inceptisol was obtained from Kaliwining Experimental Station with organic $\mathrm{C}$ content $0.81 \%$, total $\mathrm{N} 0.10 \%, \mathrm{P}_{2} \mathrm{O}_{5}$ Bray I $16 \mathrm{ppm}$, and exchangeable $\mathrm{K}, \mathrm{Na}, \mathrm{Ca}$, and $\mathrm{Mg} 0.90$, $1.25,16.75$, and $7.05 \mathrm{cmol}(+) . \mathrm{kg}^{-1}$. Additionally, the cation exchange capacity (CEC) was $27.61 \mathrm{cmol}(+) \cdot \mathrm{kg}^{-1}$ with both $\mathrm{pH} \mathrm{H}_{2} \mathrm{O}$ and $\mathrm{KCl} 1 \mathrm{~N} 7.50$ and 4.90 .

The fermented $\mathrm{CPH}$ used for this experiment was prepared for about one month anaerobic fermentation of $50 \mathrm{~kg}$ of cocoa pod husk with additional of cow urine with 1:1 ratio in a $200 \mathrm{~L}$ plastic tank, and in combination with biodecomposer containing phosphate solubilizing bacteria, lactobacillus, yeast, actinomycetes and photosynthetic bacteria to improve the biodegradation of organic materials. Laboratory analysis of final product of fermentation showed the level of organic $\mathrm{C}$ content of $0.84 \%$, total $\mathrm{N} 0.09 \%, \mathrm{C} / \mathrm{N}$ ratio 9 with $\mathrm{pH}\left(\mathrm{H}_{2} \mathrm{O}\right) 5.54$, and electrical conductivity (EC) 20.60 $\mu \mathrm{S} . \mathrm{cm}^{-1}$.
The experiment was designed by a completely randomized design (CRD), and taking into account two factors, i.e. the level of fermented $\mathrm{CPH}$ concentration and urea application, as treatments of which their effect was determined through regular growth observations and laboratory determination, i.e. soil plant analysis development (SPAD) chlorophyll readings, total dry weight of biomass, and total $\mathrm{N}$ tissue concentrations. The variation of LOF concentration levels are control (i) $0.25 \%$, (ii) $0.50 \%$, and (iii) F-CPH $1 \%$. Additionally, the rates of urea applications include the control, $10 \%, 25 \%$, and $50 \%$ of fertilizer recommendation dosages.

The manual application of urea through soil was done at 30 days after the cocoa seeds transferred to the polybags. The dosage rates used for treatments, i.e. P0, P1, P2, and P3, are determined based on the fertilizer recommendation dosage of $2 \mathrm{~g}$ per polybag per semester assuming $100 \%$ dosage rate. Different fertilizers, i.e. TSP, $\mathrm{KCl}$, and Kieserite, were also applied with dosage of $2 \mathrm{~g}, 1 \mathrm{~g}$, and $1 \mathrm{~g}$ per polybag to support with $\mathrm{P}, \mathrm{K}$, and $\mathrm{Mg}$ nutrients for crop. Additionally, the fermented $\mathrm{CPH}$ was foliar applied regularly every month during the three months observations. The volume of spray water was determined based on the plant calibration that the optimal moist condition of leaves was obtained, i.e. $12 \mathrm{~mL}$ per cocoa seedlings. The different F-CPH concentration used for treatments were determined by diluting it into distilled water ( $\mathrm{v} / \mathrm{v})$ into the corresponding levels.

Following the harvest, both oven-dried above, i.e. shoot, and belowground, i.e. root, cocoa plant biomasses were weighed, and ground in the laboratory. Additionally, they are mixed together to get a composite sample for total $\mathrm{N}$ analysis through Kjeldahl method. The $\mathrm{N}$ content expresses the average value of total cocoa seedling's biomass. The $\mathrm{N}$ tissue concentration will be used for $\mathrm{N}$ uptake 
determination from individual pot, using formula as below:

$\mathrm{N}$ uptake $=\mathrm{N}$ tissue concentration $(\%)$ $\mathrm{x}$ dry weight of tissue (g.pot $\left.{ }^{-1}\right)$

Nitrogen use efficiency (NUE) was determined to evaluate the efficiency of $\mathrm{N}$ uptake by cocoa seedlings in correspond to the crop biomass development. The NUE is calculated as following (Milroy et al., 2019):

$$
\text { NUE }=\frac{\text { Dry matter }\left(\mathrm{g} \cdot \text { pot }^{-1}\right)}{\text { N uptake }\left(\mathrm{g} \cdot \text { pot }^{-1}\right)}
$$

With values ranging from 0 to 1 , the higher NUE close to 1 means the larger proportion of $\mathrm{N}$ uptake used to develop cocoa biomass.

Additionally, the recovery efficiency of applied N (REN) is calculated to know the relative proportion of $\mathrm{N}$ uptake by plant relative to the amount of $\mathrm{N}$ applied from both LOF and urea (Dobermann \& Fairhurst, 2000). To do so, the $\mathrm{N}$ uptake by crops resulting from different treatments is corrected with $\mathrm{N}$ uptake from crops with no $\mathrm{N}$ fertilizer applications. The REN calculation can be formulated as follow:

$$
\operatorname{REN}\left(\mathrm{g} \mathrm{N} \mathrm{g}^{-1}\right)=\frac{\mathrm{N}_{1}-\mathrm{N}_{\complement}}{\mathrm{N}_{\mathrm{app}}}
$$

With:

$\mathrm{N}_{0}:$ N uptake by plant in no $\mathrm{N}$ fertilization pots
$\mathrm{N}_{1}:$ uptake by plant in $\mathrm{N}$ fertilization pots
$\mathrm{N}_{\text {app }}:$ Total amount of $\mathrm{N}$ applied from both LOF and urea

The chlorophyll content was determined through scanning the surface of leaves with SPAD meter. A hand-held device has been used to approach leaf $\mathrm{N}$ content with a non-destructive technique, and shown a potential good relationship with crop yield (Gholizadeh et al., 2017). In this research, the Pearson correlation between SPAD and tissue $\mathrm{N}$ concentration of young cocoa in response to different treatents will be evaluated (Figure 1).

\section{Statistical Analysis}

The analysis of variance (ANOVA) is used to evaluate the effect of LOF and urea applications to cocoa seedlings growth, i.e. SPAD chlorophyll as well as the calculated $\mathrm{N}$ uptake and NUE. Tukey's post hoc test is performed, when there is a significant effect of treatment to variable of observations, at $\alpha=5 \%$.

\section{RESULTS AND DISCUSSION}

The evaluated current tissue $\mathrm{N}$ concentration of cocoa seedlings indicate the nonoptimal level, $\leq 2 \%$ (Jones et al., 1991), regardless the variation in the treatments. The non-optimal condition expressed in the tissue may have been expected as related the suboptimal amount of fertilizer applied, i.e. 0 to $50 \%$ from the optimum level. As the reduced dosage of urea was aimed at evaluating the effect of LOF through foliar application, therefore the non-optimal level of $\mathrm{N}$ in the cocoa tissue revealed in this research may have suggested the low contribution of LOF.

As indicated in the previous section, the LOF $\mathrm{N}$ concentration is considered low, i.e. $0.09 \%$, or equal to about 500 times lower than the $\mathrm{N}$ derived from urea. The lower $\mathrm{N}$ content in the LOF may be related to the high potential gaseous loss of ammonia during fermentation process. As the foliar application of LOF to cocoa seedlings in this research is, mainly, attributable to its function as source of plant nutrient, instead of ameliorating soil constraints (Celestina et al., 2019), however, its application may be unable to substitute mineral-derived $\mathrm{N}$ partly.

As indicated in the previous section, the F-CPH N concentration is considered low, i.e. $0.09 \%$, or equal to about 500 times lower than the $\mathrm{N}$ derived from urea or about 100 times lower than common foliar fertilizer 

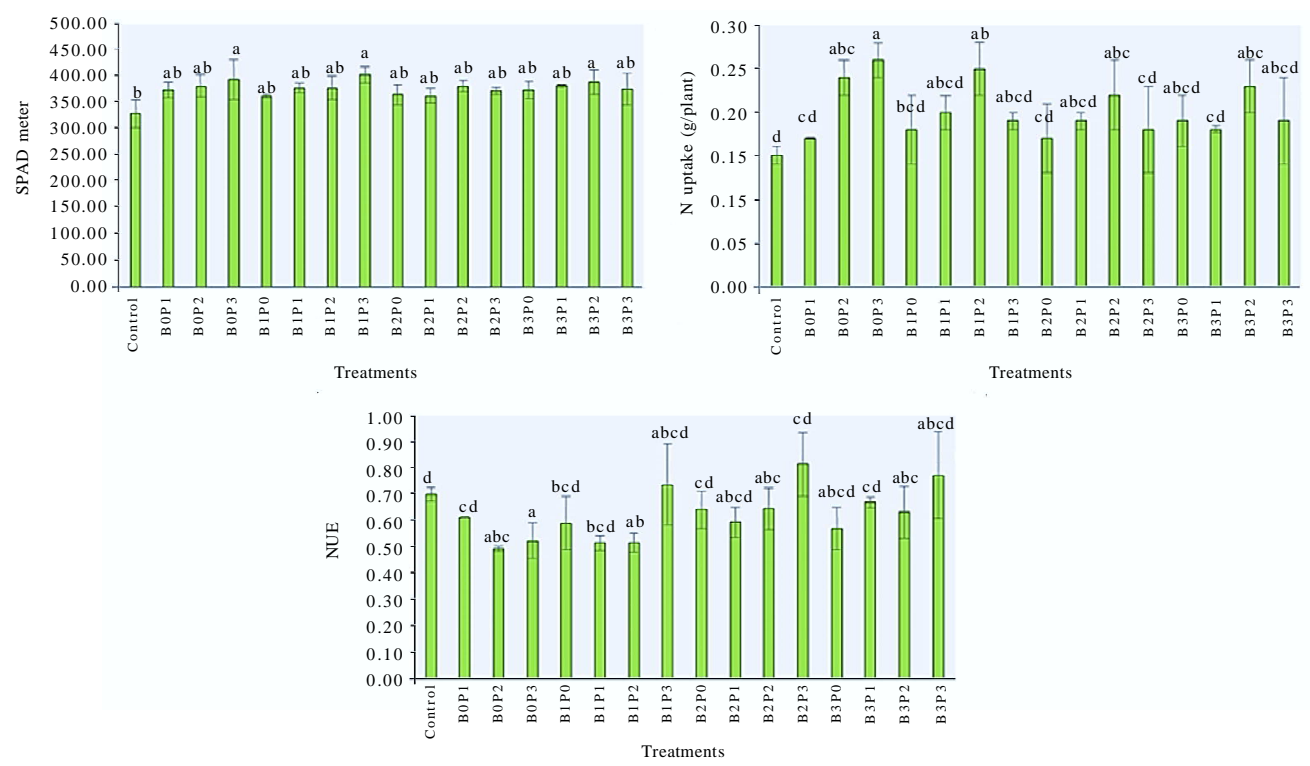

Figure 1. Observation variables, i.e. SPAD, $\mathrm{N}$ uptake and $\mathrm{N}$ use efficiency (NUE) as responses to different combination of treatments, i.e. no application of both F-CPH and urea (control), 0\% F-CPH + urea $10 \%$ of fertilizer recommendation dosage (B0P1), $0 \%$ F-CPH + urea $25 \%$ of fertilizer recommendation dosage (B0P2), $0 \% \mathrm{~F}-\mathrm{CPH}+$ urea $50 \%$ of fertilizer recommendation dosage (B0P3), F-CPH $0.25 \%$ + urea $0 \%$ of fertilizer recommendation dosage (B1P0), F-CPH $0.25 \%$ + urea $10 \%$ of fertilizer recommendation dosage (B1P1), F-CPH $0.25 \%+$ urea $25 \%$ of fertilizer recommendation dosage (B1P2), F-CPH $0.25 \%$ + urea $50 \%$ of fertilizer recommendation dosage (B1P3), F-CPH $0.5 \%$ + urea $0 \%$ of fertilizer recommendation dosage (B2P0), F-CPH $0.5 \%+$ urea $10 \%$ of fertilizer recommendation dosage (B2P1), F-CPH $0.5 \%+$ urea $25 \%$ of fertilizer recommendation dosage (B2P2), F-CPH $0.5 \%$ + urea $50 \%$ of fertilizer recommendation dosage (B2P3), F-CPH $1 \%$ + urea $0 \%$ of fertilizer recommendation dosage (B3P0), F-CPH $1 \%$ + urea $10 \%$ of fertilizer recommendation dosage (B3P1), F-CPH $1 \%+$ urea $25 \%$ of fertilizer recommendation dosage (B3P2), F-CPH $1 \%$ + urea $50 \%$ of fertilizer recommendation dosage (B3P3); Bars with different letter on the top means significant different at $\alpha=5 \%$

commercially available on the market. Nevertheless, the lower $\mathrm{N}$ content of F-CPH is about 10 times than a typical liquid organic fertilizer produced from $\mathrm{CPH}$ based components (Panggabean \& Wardati, 2015; Illing \& Mardianah, 2018). In this sense, the addition of cow urine may not clearly improve the $\mathrm{N}$ content of the final product. With typical $\mathrm{N}$ content of around 1\% after one month fermentation (Safitri et al., 2019), the 10 times lower $\mathrm{N}$ content in the F-CPH may be related to the high potential gaseous loss through ammonia during fermentation. With initial $\mathrm{N}$ content of around $5 \%$, a $35 \%$ decrease in the cow fresh urine $\mathrm{N}$ concentration within just 10 days may be expected due to the denitrification processes (Walunguru, 2012).
The evaluation of leaf $\mathrm{N}$ and chlorophyll content as indicated by SPAD readings, suggest a weak correlation between the two (Table 1a). In the present research, the Total Kjeldahl $\mathrm{N}$ was determined not from pure leaf tissue, instead the total biomass of seedlings as collected from both above and below the ground. Therefore, it is suggested that the use of SPAD readings to approach of leaf $\mathrm{N}$ status may still be unconfirmed. Furthermore, as already reported elsewhere (Xiong et al., 2015), the relationship between leaf $\mathrm{N}$ content and SPAD readings may vary depending on the environmental factors and leaf features of specific crops. The correlation analysis made between $\mathrm{N}$ uptake and SPAD readings suggest the improved of relation between the two 
(Figure 1b). As taking into account the total dry biomass of cocoa seedlings for calculation, the increase in the correlation coefficient may suggest the important of sample type specifically to the final interpretation.

SPAD readings indicate the significant effect of urea and its combination with LOF to the increase in the chlorophyll content by 10-20\% to control (Figure 2, SPAD). The significant highest SPAD reading was confirmed at $50 \%$ of urea fertilizer dosage in combination with both no and $0.25 \%$ concentration of LOF. It is, however, suggested that the increase in the LOF concentration to $0.50-1.00 \%$, in the same level of urea dosage, has decreased the chlorophyll content down to below $10 \%$. As no positive strong correlation were observed between SPAD readings and $\mathrm{N}$ uptake (Table 1), therefore it is assumed that different specific factor existed to determine the effect of additional of LOF concentration. In this context, it is suggested the leaf characteristics variabilities in the individual level of plant providing a key factor due to the high likely of homogeneity of environmental condition in the green house scale.

Given that all SPAD readings levels of cocoa leaves in the current research were higher than 300 , above 40 as the minimum point in correspond to carotenoid level in leaves (Netto et al., 2005), it may point out the enhanced the photosynthetic processes.

As $\mathrm{N}$ may influence on the crop photosynthesis (Bassi et al., 2018), the suboptimal $\mathrm{N}$ status in the leaves, as discussed earlier, is attributable to the current chlorophyll level.
Yet, due to the weak relationship to leaf $\mathrm{N}$ concentration (Table 1), therefore in this research the result of SPAD readings may not necessarily indicate the leaf $\mathrm{N}$ status of cocoa seedlings.

Furthermore, statistical analysis suggest the significant different effect of treatments to cocoa $\mathrm{N}$ uptake. The average increase of about $40 \%$ in compare to control was observed. The significant highest increase was resulted from $25 \%$ of urea application in the absence of F-CPH treatment (B0P3) with about $77 \%$ increase to control. Generally, the $\mathrm{N}$ uptake by cocoa tends to decrease with the increase in the concentration of LOF.

Similarly, in the same level of LOF concentration, the $\mathrm{N}$ uptake is consistently decreasing from $\mathrm{P} 2$ to $\mathrm{P} 3$ throughout the treatment combinations (Figure 2). This means that there is a limit of point at which the relation of F-CPH concentration to $\mathrm{N}$ uptake is still positive. Next to this point, its effect may be negative in terms of reducing the cocoa $\mathrm{N}$ uptake. Though the use of same material as compost was reported clearly to improve the nutrient uptake (Kayode et al., 2018), in the present research the application of LOF as source of nutrient for cocoa seedlings may still be limited.

The NUE values are ranging from 0.50 to 0.80 , indicating a variation in terms of treatment effect to cocoa seedling growth. The higher NUE values were observed in the treatments with highest level of urea, i.e. B1P3, B2P3, B3P3, with NUE values close to 0.80 . The

Table 1. Matrix correlation $\left(\mathrm{R}^{2}\right)$ of $\mathrm{N}$ variables used in this research $(\mathrm{N}=46)$

\begin{tabular}{|c|c|c|c|c|c|c|c|}
\hline & SPAD meter & Dry weight & Total N & $\mathrm{N}$ uptake & NUE & REN & $\mathrm{N}$ rate \\
\hline SPAD meter & 1 & & & & & & \\
\hline Dry weight & 0.34253 & 1 & & & & & \\
\hline Total N & 0.06898 & -0.34126 & 1 & & & & \\
\hline $\mathrm{N}$ uptake & 0.30846 & $0.42472 *$ & $0.69546 *$ & 1 & & & \\
\hline NUE & 0.00267 & $0.42550 *$ & $-0.97805 *$ & $-0.62912 *$ & 1 & & \\
\hline REN & -0.12442 & -0.30716 & 0.29817 & 0.01010 & -0.29391 & 1 & \\
\hline $\mathrm{N}$ rate & $0.43212 *$ & $0.75089 *$ & -0.22520 & 0.34905 & 0.31549 & -0.39763 & 1 \\
\hline
\end{tabular}




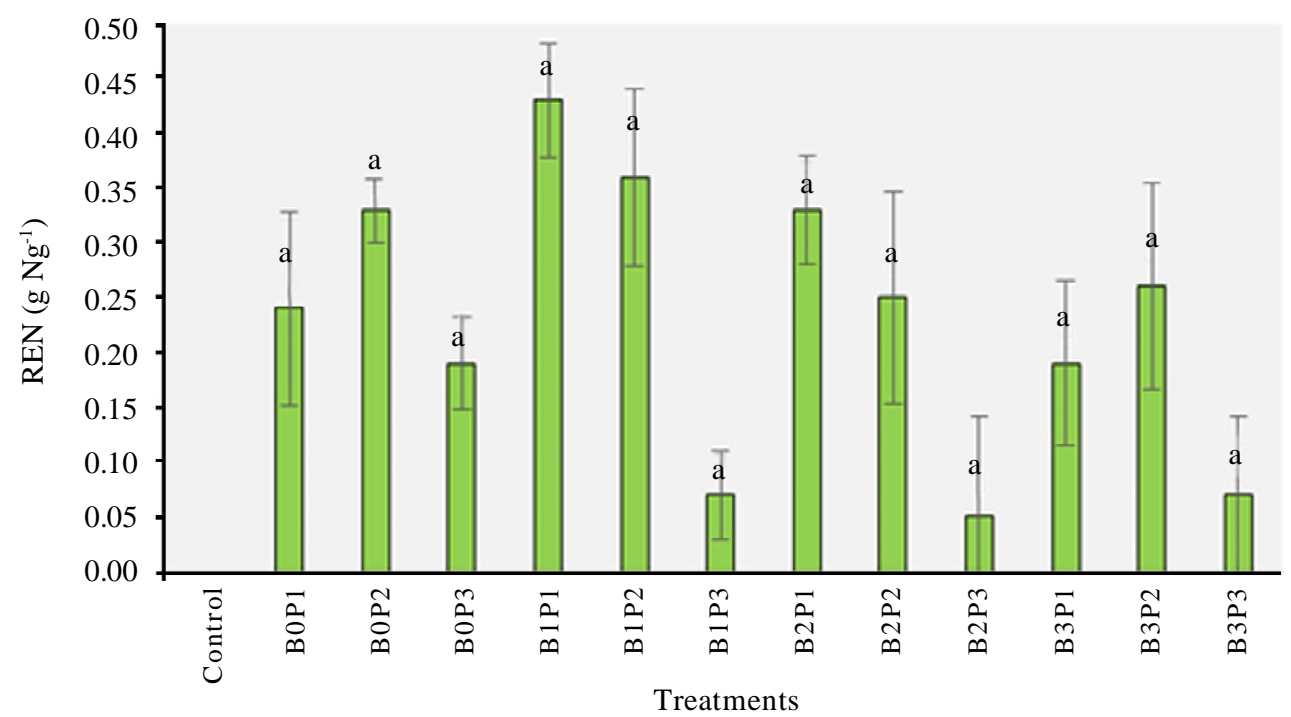

Figure 2. Recovery efficiency after N application (REN) with no application of both F-CPH and urea (control), $0 \% \mathrm{~F}-\mathrm{CPH}+$ urea $10 \%$ of fertilizer recommendation dosage (B0P1), $0 \% \mathrm{~F}-\mathrm{CPH}+$ urea $25 \%$ of fertilizer recommendation dosage (B0P2), $0 \% \mathrm{~F}-\mathrm{CPH}+$ urea $50 \%$ of fertilizer recommendation dosage (B0P3), F-CPH $0.25 \%$ + urea $10 \%$ of fertilizer recommendation dosage (B1P1), F-CPH $0.25 \%$ + urea $25 \%$ of fertilizer recommendation dosage (B1P2), F-CPH $0.25 \%$ + urea $50 \%$ of fertilizer recommendation dosage (B1P3), F-CPH $0.5 \%$ + urea $10 \%$ of fertilizer recommendation dosage (B2P1), F-CPH $0.5 \%$ + urea $25 \%$ of fertilizer recommendation dosage (B2P2), F-CPH $0.5 \%$ + urea $50 \%$ of fertilizer recommendation dosage (B2P3), F-CPH $1 \%+$ urea $25 \%$ of fertilizer recommendation dosage (B3P1), F-CPH $1 \%$ + urea $25 \%$ of fertilizer recommendation dosage (B3P2), F-CPH $1 \%+$ urea $50 \%$ of fertilizer recommendation dosage (B3P3)

latter treatment shows a significantly highest effect to NUE in compare to different treatment. In this case, the higher NUE means the positive effect of combination of both urea and F-CPH to the dried cocoa seedling biomass. The high NUE value for control may have indicated the high contribution of soil-derived $\mathrm{N}$. Though the total $\mathrm{N}$ in the soil may be designated as low $(<0.30 \%)$, the high $\mathrm{N}$ uptake by cocoa seedling is implying the high $\mathrm{N}$ minerals available in the soil. However, the stable condition of soil organic matter as indicated by $\mathrm{C} / \mathrm{N}$ below 10 may confirm the potentially high status of $\mathrm{N}$ minerals in the soil.

Additionally, data suggest the effect of F-CPH to the increase in the NUE in combination with specific level of urea. With addi- tional F-CPH in the treatments, the NUE values have increased to some extent from the point where no LOF is applied. The NUE increase is corresponding to the increase in the urea rate, which means that the higher urea rate (P3) the larger the NUE increase. With $50 \%$ of urea recommendation dosage, the increase in NUE is above $40 \%$ up to $55 \%$ compared to non- F-CPH applied treatments. The increase in the NUE through F-CPH foliar application is attributable to the improvement in cocoa seedling biomass. The positive effect of organic source material to improve the efficiency of mineral fertilizer for cocoa seedlings has been reported (Prastowo et al., 2014).

REN data interpretation indicates the higher values for treatments with lower level 
of urea applications, i.e. P1 and P2 (Figure 2). This means that cocoa seedlings take $\mathrm{N}$ higher than the amount of being applied. At the higher level of urea in P3, cocoa take $\mathrm{N}$ below to $0.10 \mathrm{~g}$ per $\mathrm{g}$ of $\mathrm{N}$ applied at the corresponding level of F-CPH. However, it can be concluded that most of cocoa taking the amount of $\mathrm{N}$ for their growth dominantly from soil, which is higher than the amount of F-CPH and urea derived N. As discussed before, the high contribution of soil derived $\mathrm{N}$ is likely attribut-able to the high $\mathrm{N}$ minerals available in the soil.

In the absence of LOF, cocoa is taking $\mathrm{N}$ about $0.20-0.30 \mathrm{~g}$ per $\mathrm{g}$ of $\mathrm{N}$ applied from urea with lower dosage, i.e. P1 and P2 (Figure 2). With the increase in the urea rate of up to $50 \%$ from recommendation dosage (P3), the REN value is decreased implying the contribution from the input of $\mathrm{N}$. In this level, the REN is down to below $50 \%$ showing the lower amount of $\mathrm{N}$ required in compare to the $\mathrm{N}$ inputs. Environmental factors may also be responsible to the response occurred following the $\mathrm{N}$ addition, such as soil fixation, volatilization and leaching. However, soil $\mathrm{N}$ balance during the treatment is unable to confirm in the present research.

The optimal rate of urea to the respective LOF concentration is considered the corresponding point at which the cocoa $\mathrm{N}$ uptake is at the highest level from the series of treatments (Figure 3). The asymptotic type of curves indicates the optimal rate of urea occurred at the level before the highest point, ranging from 0.5 to $1 \mathrm{~g}$ urea per pot where it is varied depending on the F-CPH levels. In the absence of F-CPH (B0), the estimated optimal rate of urea is around 1.20 g per pot. The increase in the LOF levels is providing different optimal level of urea around $0.70 \mathrm{~g}$ per pot. The higher rate of urea from this range is expected to decrease the cocoa seedlings $\mathrm{N}$ uptake, and ends up with the decreasing in the urea application efficiency.

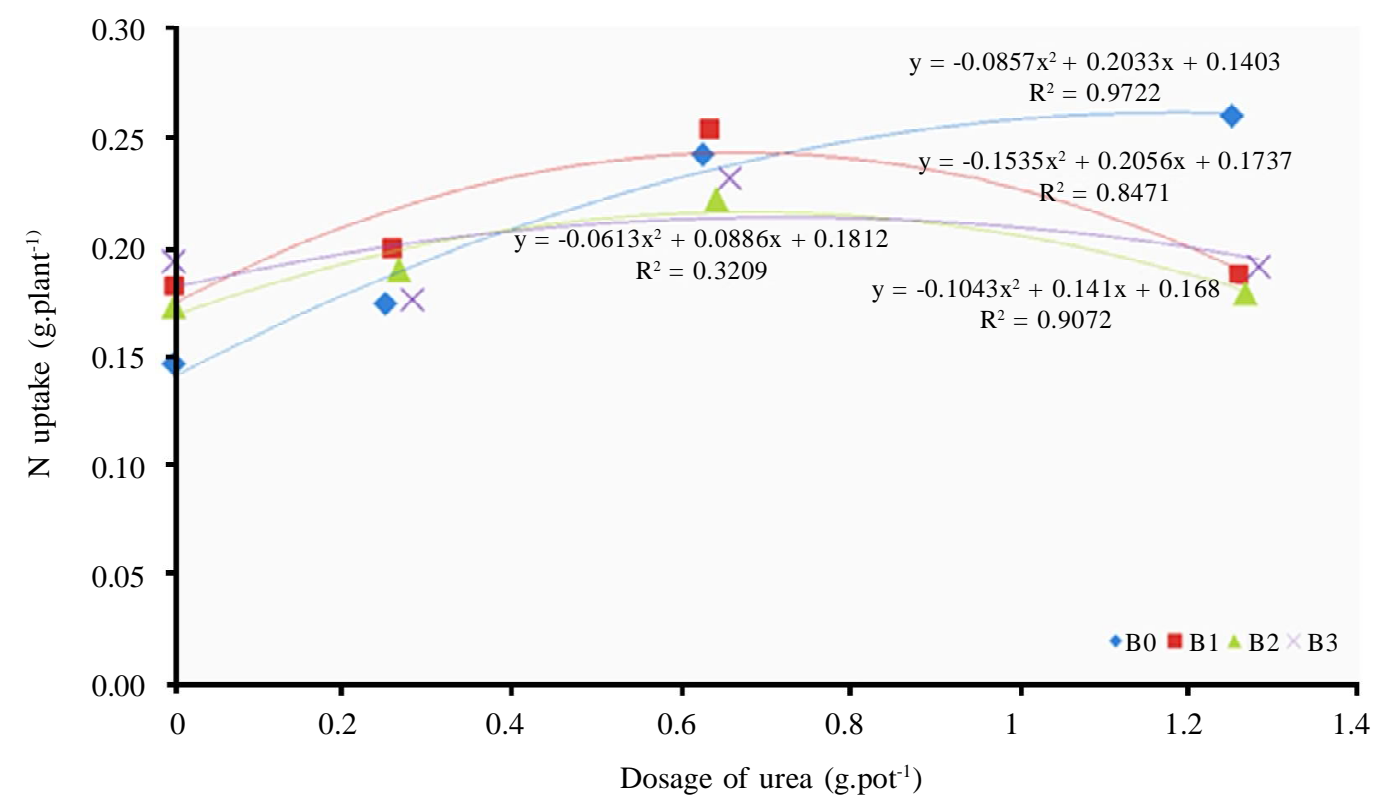

Figure 3. $\mathrm{N}$ optimal application in response to different combination treatments of F-CPH and urea (B0 $=0 \% \mathrm{~F}-\mathrm{CPH}, \mathrm{B} 1=0.25 \% \mathrm{~F}-\mathrm{CPH}, \mathrm{B} 2=0.5 \% \mathrm{~F}-\mathrm{CPH}, \mathrm{B} 3=1 \% \mathrm{~F}-\mathrm{CPH})$ 
Additionally, the higher amount of F-CPH applied shows to decrease the optimal dosage of urea required in compare to no $\mathrm{F}-\mathrm{CPH}$ application (B0) (Figure 3). In the absence of F-CPH, the optimal dosage is about $1.20 \mathrm{~g}$ per pot, yet decreases to the point close to $0.70 \mathrm{~g}$ per pot with the increasing of its concentration. Therefore, though its use as source of nutrients is limited, current research may indicate the potential utilization of LOF through foliar spray to increase the efficiency of urea application.

\section{CONCLUSIONS}

SPAD readings indicate the significant effect of urea to the increase in the chlorophyll content by 10-20\% to control. Yet, in the same level of urea rate, the chlorophyll content is down to below $10 \%$ with the increase in the F-CPH concentration to $0.50-1.00 \%$. No strong correlation observed between SPAD readings and $\mathrm{N}$ content. Furthermore, the average increase of $\mathrm{N}$ uptake of about $40 \%$ resulting from treatments in compare to control was observed. The significant highest increase, of about $77 \%$ in compare to control, was resulted from $25 \%$ of urea application in the absence of F-CPH application. It is found its strong positive correlation to the rate of $\mathrm{N}$ application. The effect of combination of both urea and F-CPH demonstrate a NUE value ranging from 0.50 to 0.80 . Its value has been increased with corresponding to the increase in the urea rate. REN data indicates the higher values for treatments with lower level of urea applications. It is going down with the increase in the urea rate. The optimal dosage for cocoa seedling is obtained ranging from 0.5 to $1 \mathrm{~g}$ urea per pot where it is varied depending on the F-CPH levels. In the absence of $\mathrm{F}-\mathrm{CPH}$, the estimated optimal rate of urea is around $1.20 \mathrm{~g}$ per pot, and going down to close to $0.70 \mathrm{~g}$ per pot with the increase in the level of F-CPH. Though its use as source of nutrients is limited, current research may indicate the potential utilization of LOF through foliar spray to increase the efficiency of urea application.

\section{REFERENCES}

Ayeni (2020). Effect of combined cocoa pod ash and NPK fertilizer on soil properties, nutrient uptake and yield of maize (Zea mays). Journal of American Science, 6, 79-84.

Bassi, C.; M. Menossi \& L. Mattiello (2018). Nitrogen supply influences photosynthesis establishment along the sugarcane leaf. Scientific Reports, 8, 1-13.

Campos-Vega, R.; K.H. Nieto-Fuguerora \& B.D. Oomah (2018). Cocoa (Theobroma cacao L.) pod husk: renewable source of bioactive compounds. Trends in Food Science \& Technology, 81, 172-184.

Celestina, C.; J.R. Hunt, P.W.G. Sale \& A.E. Franks (2019). Attribution of crop yield responses to application of organic amendments: A critical review. Soil \& Tillage Research, 186, 135-145.

Dobermann, A \& T. H. Fairhurst (2000). Rice: Nutrient Disorders \& Nutrient Management. Handbook Series. International Rice Research Institute. Manila.

Fageria, N.K. \& V.C. Baligar (2005). Enhancing Nitrogen Use Efficiency In Crop Plants. pp, 97-185. In: D.L. Sparks (Ed). Advances In Agronomy, 80. Elsevier Academic Press, California.

Gholizadeh, A.; M. Saberioon; L. Boruvka; A. Wayayok \& M.A.M. Soom (2017). Leaf chlorophyll and nitrogen dynamics and their relationship to lowland rice yield for site-specific paddy management. Information Processing In Agriculture, 4, 259-268.

Illing, I. \& S. Mardianah (2018). Analisis kadar nitrogen pupuk organik cair limbah kulit kakao dan tandan kosong kelapa sawit dengan starter EM-4. Jurnal Dinamika, 9, 29-37. 
Jones, J.B.; B. Wolf \& H.A. Mills (1991). Plant Analysis Handbook. A Practical Sampling, Preparation, Analysis, and Interpretation Guide. Micro-Macro Publishing, Inc. Georgia.

Kaba, J.S.; S. Zerbe; D. Zanotelli; A.A. Abunyewa \& M. Tagliavni (2018). Uptake of nitrogen by cocoa (Theobroma cocoa $\mathrm{L}$.) trees derived from soil decomposition of gliricidia (Gliricidia sepium Jacq.) shoots. Acta Hortic, 1217, 263-269.

Kayode, C.O.; G.O. Adeoye; D.T. Ezekiel-Adewoyin; O.E. Ayanfe; D.O. Ogunleti \& A.F. Adekunle (2018). Influence of cocoa pod husk-based compost on nutrient uptake of okra (Abelmoschus (L.) MOENCH) and soil properties on Alfisol. Communications in Soil Science and Plant Analysis, 49, 2113-2122.

Milroy, S.P.; P. Wang \& V.O. Sadras (2019). Defining upper limits of nitrogen uptake and nitrogen use efficiency of potato in response to crop $\mathrm{N}$ supply. Field Crop Research, 239, 38-46.

Netto, A.T.; E. Campostrini; J.G. de Oliviera \& R.E. Bressan-Smith (2005). Photosynthetic pigments, nitrogen, chlorophyll a fluorescence and SPAD-502 readings in coffee leaves. Scientia Horticulturae, 104, 199-209.

Nurhaita; N. Definiati, U. Santoso; S.A. Akbar \& Y.L. Henuk (2018). The effect of fermented cocoa pod (Theobroma cacao) husk supplemented with mineral on in vitro digestibility, rumen bacteria population and rumen liquid characteristics. IOP Conf. Ser.: Earth Environmental Science, 122, 1-6.

Oyewole, O.S.; I.O.J. Ajayi \& R.I. Rotimi (2012). Growth of cocoa (Theobroma cacao L.) seedlings on old cocoa soils amended with organic and inorganic fertilizers. African Journal of Agricultural Research, 7, 3604-3608.

Panggabean, P. \& Wardati (2015). Effect of liquid organic fertilizer and compost rind cocoa to the growth of oil palm seedlings (Elaeis gueneensis Jacq.) in the main nursery. JOM Faperta, 2, 1-11.
Prastowo, E.; N.F. Hikmah \& J.B. Baon (2014). Ammonia volatilization in cocoa farm as affected by sugarcane filter cake supply at different urea and soil moisture levels. Pelita Perkebunan, 30, 208-209.

Prastowo, E. \& J.B. Baon (2020). Factors determining the characteristics of cocoa soil in Sulawesi. Pelita Perkebunan, $36,32-46$.

Ribeiro, M.A.Q.; J.O. da Silva, W.M. Aitken, R.C.R. Machado \& V.C. Baligar (2008). Nitrogen use efficiency in cacao genotypes. Journal of Plant Nutrition, 31, 239-249.

Safitri, A.; A. Roosdiana; A. Srihardyastutie \& Masruri (2019). Fermentation of cow urine collected from Ngabab village, Malang: its potential as liquid fertilizer. IOP Conf. Ser.: Earth Environmental Science, 122, 1-5.

Sugiyanto; J.B. Baon \& KA. Wijaya (2008). Soil chemical properties and nutrient uptake of cocoa as affected by application of different organic matter and phosphate fertilizers. Pelita Perkebunan, 24, 188-204.

Vásquez, S.Z.; D.P.C. Neto; G.V.M. Pereira; L.P.S. Vandenberghe; P.Z. de Oliviera; P.B. Tiburcio; H.L.G. Rogez; A.G. Neto \& C.R. Soccol (2019). Biotechnological approaches for cocoa waste management: A review. Waste Management, 90, 72-83.

Vriesmann, L.C.; R.F. Teófilo \& C.L.O. Petkowicz (2012). Extraction and characterization of pectin from cacao pod husks (Theobroma cacao L.) with citric acid. LWT-Food Science and Technology, 49, 108-116.

Walunguru, L. (2012). Quality of liquid organic fertilizer from cattle urine on different time store. PARTNER, 19, 26-32.

Xiong, D.; J. Chen; T. Yu; W. Gao; X. Ling; Y. Li; S. Peng \& J. Huang (2015). SPADbased leaf nitrogen estimation is impacted by environmental factors and crop leaf characteristics. Scientific Reports, 5, $1-12$.

$$
* * 0 * *
$$

